\title{
Research on the Teaching Archives Construction of University Excellent Courses
}

\author{
Mei Zhang \\ Archives \\ Linyi University \\ Linyi, China \\ Zhangmei7596@163.com
}

\author{
Peijiang Chen \\ School of Mechanical and Vehicle Engineering \\ Linyi University \\ Linyi, China \\ chenpeijiang@163.com
}

\begin{abstract}
The construction of excellent courses in colleges and universities is an important measure to improve the teaching quality. The archiving and management of teaching materials is an important part of the construction of excellent courses. This paper introduces the connotation and archiving contents of the teaching archives construction in excellent courses, and puts forward some suggestions on how to further improve the network resources construction of excellent courses and archives management. The main recommendations include improving the management system, determining the archiving principles, informatizing the teaching information, establishing incentive and restraint mechanisms, and improving the utilization of teaching archives. These measures are expected to strengthen the construction and management of archives and of excellent courses and promote the using effect of the excellent courses in colleges and universities.
\end{abstract}

Keywords-Excellent course; Teaching archives; Archiving contents; Management countermeasure

\section{INTRODUCTION}

As the products of school, the courses are main channels in colleges and universities. The excellent course is high quality teaching resource, and it is an important component of education quality engineering and teaching reform engineering. It is an important measure to update education concept and improve education quality and personnel training quality. It can reflect the teaching quality and characteristics of school running. In the process of building excellent courses, a series of teaching materials with preserving value have been produced, including text, graphics, audio and video, courseware, exams and reference materials for learning, which constitute the teaching archives of excellent courses in colleges and universities. These teaching resources are rich in content, and provide teaching resources sharing to learners both inside and outside the school through the network platform. The valuable knowledge and utilization value promote the improvement of teaching quality in China. At the same time, it also puts forward higher requirements and challenge for archives management. The important application way of the excellent course teaching resources is network teaching. The teaching and learning both are separated in time and space, and the independent study occupies larger proportion than before[1].

This study was supported by the Undergraduate Teaching Reform Project of Shandong Province Higher Education in 2018 (No. M2018X062) and the Teaching Quality Engineering Projects of Linyi University in 2016, 2017 and 2018.
The excellent courses focus on the use of information technology teaching methods, reflecting the advanced teaching philosophy, teaching methods and teaching methods, with rich teaching content, strict teaching management and excellent teaching results. The management and use of the excellent course teaching materials has important function, direct impacting on the radiation of excellent courses and the effective improvement of teaching quality. Promoting the process of teaching archives information management is worthy for the teaching management and archives management staff [2].

Based on the analysis of the main archives contents of excellent teaching materials, the suggestions and countermeasures to strengthen the management of the teaching materials is puts forward to improve the sustainability of excellent courses construction and give play to the better platform functions.

\section{FUNCTION OF TEACHING ARCHIVES CONSTRUCTION IN EXCELLENT COURSES}

In the process of course construction, the teaching archives is a systematic collection of documents that records the teaching contents, teaching forms, teaching methods, teaching conditions and student learning. It has the characteristics of teaching, completeness and reality. Establishing and perfecting the teaching files plays an important role in strengthening the construction of excellent courses, improving teaching quality and teaching management.

\section{A. Accumulate course teaching materials that is conducive to teaching reform}

The construction of excellent course is a long-term, continuous practice process that can not be completed overnight. It need some foundation of teaching philosophy, teaching organization and teaching methods and accumulation of a large number of teaching materials. Establishing and perfecting teaching archives can provide true, objective and rich information resources for the teaching, research and reform of the excellent course, so as to provide a stable and reliable platform for accumulating teaching experiences and teaching materials and to support the sustainable development of the courses. 


\section{B. Promote the building of teaching team}

The main part of the construction of excellent courses is the teacher. In order to create and improve the excellent courses, the enthusiasm of teachers must be mobilized. The excellent courses provide an operating platform for the design and teaching of the courses. Different roles of teachers should know their own tasks, and their sense of responsibility should be enhanced. The construction of teaching archives provides the basis for assessing the work of the team and helps to mobilize the enthusiasm of team members.

\section{Promote the implementation of excellent courses}

The construction of excellent courses is actually a process of gradual deepening. The changes from idea updating to course designing to teaching methods are often carried out in stages and are the cycle of "innovation - consolidating and implementing - re-innovation". In the process of "consolidating and implementing", the teaching records need to be used to record the implementation results. Each "innovation" is compared with the results of the previous course implementation to propose the improvement plan of the course, which needs to be provided by the teaching archives. Through the teaching archiving, the results of the excellent courses can be fully implemented and continuously improved.

\section{Provide basis for the evaluation of excellent courses}

The teaching archives record and reflect all the valuable content related to the construction of excellent courses. By the teaching archives, the achievements of the course construction in each period can be found, and the contribution of each teacher to the course construction can be understood. These are the evidences of the inspection and evaluation of the construction of excellent courses, which ensures that the accuracy and effectiveness of the examination and evaluation of the excellent courses [3].

\section{E. Provide social services for off-campus learners}

Today's excellent courses exist in the form of online courses. These online resources with high quality are more conducive to the promotion of popular education. The teaching materials of excellent courses have made the learners extend to all over the country and even the whole world, solving the problems of insufficient teaching resources and insufficient course resources for colleges and society [4].

\section{CONTENT OF EXCELLENT COURSE ARCHIVES CONSTRUCTION}

\section{A. Connotation of excellent course archives}

Excellent course is an exemplary course, it has first-class teachers, first-class teaching content, first-class teaching methods, first-class teaching materials, first-class teaching management and so on. There are quite a lot of archives in excellent courses.

Such as course construction planning, application materials, mid-term assessment, final acceptance inspection, which can reflecting the construction process. There are some materials that can represent the generality of teaching, including syllabus, teaching plan, experiment instruction, test database, and so on. But the more are personal information of teachers, such as typical lesson plans, multimedia courseware, teaching videos and teaching research results.

Correct definition of the content of excellent course archives is to determine the material attribution. In the process of declaration, assessment, operation of the excellent course, the basic materials are electronic documents. But whether electronic or paper materials should be stored.

- Materials produced during the course of excellent courses construction

The Archiving materials produced in the course construction of excellent courses include the documents in the whole process of declaration, review, operation, inspection and acceptance. For example: the need material submitted in a university are syllabus, teaching plans, exercises, practical guidance, references and the teacher's on-site teaching video and other information.

\section{- Materials produced during the course running}

In general, the excellent courses should constantly update the online content in the operational phase. The teaching resources of the excellent course can be divided into two categories, tangible and intangible resources. The tangible resources include teaching content, teaching staff, teaching conditions, when there is each major change, the corresponding material should be changed and archived. The intangible resources refers to the teaching concept and teaching guiding ideology contained in the course construction and reform, which is the soul of the construction of excellent courses. If the course director and the chief teachers have been adjusted, the course teaching philosophy may also be changed.

In addition, during the examination and acceptance of the excellent course, the competent authorities may review them and decide whether or not to retain the title of the excellent course [5].

\section{B. Content of excellent course archives}

In general, the archives contents of the excellent course and the archives contents of the general teaching management are not much different in form [6]. The main content of the excellent course archives should include the following aspects.

\section{- Competent documents}

The main teaching archives of competent documents include the policies, guidance documents that the higher education departments and schools issue, professional training programs and the syllabus, teaching calendar and other information that course teaching team set out.

\section{- Review materials}

The teaching archives of evaluation materials o mainly include teaching team, course description, course construction planning, teaching videos, supporting materials, course resources, self-evaluation and other materials.

- Teaching materials 
The teaching materials mainly include self-compiled teaching materials, multimedia courseware, teaching reference materials, experimental instruction books, exercise books, test papers, test papers analysis, and so on.

- Teaching monitoring

The teaching monitoring archives include the grades registration form, lectures notes, teaching situation check record, teaching summary and other materials.

\section{- Teacher business}

The teaching business archives mainly include teaching research plan, teaching reform, teaching papers and subject competition awards.

\section{- Other archives}

The other types of teaching archives mainly include student interview records, teaching quality questionnaire, teaching and research activities records, construction effect feedback information and other materials.

\section{CONSTRUCTION AND MANAGEMENT MEASURES OF EXCELLENT COURSE TEACHING ARCHIVES}

The construction of excellent courses is a window of teaching quality in colleges and universities. It is both an honor and a responsibility for participants. As a member of the excellent course builder, the archives management staff should actively innovate and make the archives management work well. Especially in the current situation of rapid development of network technology, it is necessary to promote the informatization management of teaching archives and to realize the informatization service function of excellent course teaching archives.

\section{A. Establish platform awareness and improve the management system}

It is need to know that the awareness is the basis for proper action. In the construction of excellent courses, the builder should fully recognize the role of teaching archives in the construction of excellent courses and the improvement of teaching quality. The specialized excellent course construction committees can be established to strengthen the organization and leadership of teaching archives. The teaching archives management can be closely linked with daily teaching and research activities. The regular inspection assessment and incentive system of teaching archives can be established to urge the smooth development of the course construction.

In addition, the archives awareness of excellent course teachers and archivists should be deepened. They are the largest groups of establishing and utilizing the excellent course archives in colleges and universities. Their archival awareness directly affects the archiving rate and completeness rate of excellent course archives. Therefore, they should initiate their interest and motivation to accumulate archives and increase their enthusiasm for archiving so that they can take the accumulation and archiving of the excellent course documents and materials as an important part of their work.

\section{B. Determine the archiving principles of excellent course teaching materials}

The teaching archives of excellent course is not only a record of excellent course teaching activities, but also the basis for evaluating the excellent course leaders and teachers for carrying out teaching activities. It is an important material for teaching evaluation. The establishment of excellent course archives must adhere to the principles of truthfulness, completeness, standardization, effectiveness and continuity [7].

- The integrity of archives.

Archives should be set up for all the excellent courses in colleges and universities. The all teaching materials of the excellent courses should be fully archived and the integrity must be kept.

- The authenticity of archives.

The archives of excellent course must be a true record of course teaching to retain a variety of raw data, may not be modified.

- The standardization of archives.

According to the requirements of the teaching archives, the archives of excellent courses should specify the archiving scope, the requirements of classification and arrangement, the archiving forms of different teaching vectors and the filing time, so as to form a standardized course archives.

- The effectiveness of archives.

The archives of excellent course should be archived as a unit. The collection and archiving works can be done at the beginning or end of the semester.

\section{- The continuity of archives,}

the teaching file of each link in the teaching process can not be missing. The teaching activities of every year should be documented to from a continuous file. Then, the history of the construction and reform of the course teaching can be gotten, so as to support the research and sustainable development of the excellent course.

\section{Achieve the information and network of teaching archives}

With the rapid development of communication technology and computer technology, the informatization and networking of teaching archives are the key directions of excellent cores construction. The effective usage of share of teaching resources by computer network can provide users with more convenient, vivid, rich information services.

It is necessary to combine the archives construction and the excellent course itself, make the network as a carrier, establish a teaching mode characterized by sharing, opening up and three-dimensional, and provide sharing resources to teachers and students both inside and outside the school through the course network.

The core of teaching archives information construction is resource. The content that is directly related to the teaching work is classified and sorted out, and various thematic databases are constructed. The teachers of the course group can 
send the teaching documents through the Internet and they can discuss teaching problems online so as to maximize the sharing of the archival materials.

For example, the teachers can design and improve the test questions library to carry out the separation of examination from teaching, making teachers freed from the heavy work. And it can provide a strong basis for the reasonable resources configuration and scientific decision-making in the teaching management [8].

\section{Establish incentive and restraint mechanisms to mobilize teachers' enthusiasm}

Teachers are the main body of the construction of excellent courses, and the main body of the management and application of teaching archives. The teachers should be as the main subject of the management system of teaching archives, so as to mobilize their enthusiasm. The teaching archives management is an important part of the course construction, and the teaching group should have the specialized management authority and responsibility. It is important to reasonably assess and calculate the workload of teachers participating in the construction of teaching archives, integrate them into teachers' work performance assessment, and closely link workload disbursement and workload assessment in the promotion of professional titles. It is necessary to enhance teachers' sense of responsibility and enthusiasm, truly standardize the management of teaching archives, and improve the quality of teaching archives management.

\section{E. Enhance the usage effectiveness of the excellent course resources}

It is the final goal of the archiving management to improve the usage effect, which is to estimate the archives' value and the level of archives work. The implementation of excellent courses is to use the modern educational information technology to make the course and the related contents into Internet, so as to realize the sharing of high quality teaching resources. It requires that the teaching archives business should be organized normatively, and the course archives information should be refined so as to maintain the organic connection of the course documents and materials. It is need to fully mobilize the archives management staff to use information technology means to implement scientific management and effective development and utilization of archives resources in a timely manner to provide services for the teaching and research personnel to promote the maximum sharing of archives resources. The level of university course construction and the teaching quality should be gradually improved. The course resources center should be established and opened. The teaching resources with its own characteristics are sent to the whole society, the course resources can be developed and utilized maximally.

\section{CONCLUSIONS}

With the continuous development of education, many universities regard the construction of excellent courses as an important means to improve the teaching quality and enhance the level of school running. The construction and management of teaching materials are the important contents of the excellent courses. Teaching staff and records managers should fully realize the importance of their work. It is need to actively use professional knowledge, scientific and standardized management tools, modern computer network information technology to improve the management of teaching archives.

In colleges and universities, the construction and management of excellent course teaching archives, especially the application of network and information, is a subject that needs long-term exploration and research. It is necessary to learn more about foreign research achievements and promote the scientific management and standardization of excellent course archives information resources, and promote the effective use of education resources with high quality. It can provide solid foundation to improve the teaching level and of teaching quality.

\section{ACKNOWLEDGMENT}

This study was supported by the Undergraduate Teaching Reform Project of Shandong Province Higher Education in 2018 (No. M2018X062) and the Teaching Quality Engineering Projects of Linyi University in 2016, 2017 and 2018.

\section{REFERENCES}

[1] Y. Tian, Y. Chen, Design and Implementation of E-portfolio in Webbased Courses, China Medical Education Technology, 19(6) (2005) 461463.

[2] H. Bai, The Network Resource Construction of Fine Courses of Inner Mongolia Colleges and Universities from the Perspective of Archival Management, Journal of Inner Mongolia University of Finance and Economics, 12(4) (2014) 142-144.

[3] H. Lian, The Function of Teaching Archives in the Construction of Excellent Courses, Lantai World, (24) (2008) 30-31.

[4] H. Bai, Countermeasures Analysis of Teaching Archives Management of College Online Courses, Journal of Inner Mongolia University of Finance and Economics, 15(5) (2017) 150-152.

[5] P. Chen, The Construction of the Special Course of Automobile Electronic and Electrical Equipment, Advances in Social Science, Education and Humanities Research, 93 (2017) 130-133.

[6] M. Zhang, P. Chen, Research on the Informatization Construction of University Archives Management, Advances in Social Science, Education and Humanities Research, 157 (2017) 342-345.

[7] Y. Gao, The Filing Scope and Requirement for the University Quality Project: Taking the National Classical Course as the Example, Archives and Construction, (5) (2011) 20-21.

[8] R. Chen, M. Xu, Y. Tao, M. Cao, Z. Ye, Establishment of Teaching Files in Medicine Curriculum Construction, Research in Medical Education, 7(1) (2008) 5-6. 